\title{
Autophagy turns specific: the discovery of p62 and NBR1 as autophagy cargo receptors
}

\author{
Geir Bjørkøy \\ From 16th International Charles Heidelberger Symposium on Cancer Research \\ Coimbra, Portugal. 26-28 September 2010
}

Cellular proteins and organelles are constantly damaged as a result of cell-stress, expression of mutated genes or aging by itself. Autophagy is the principle cellular mechanism for turnover of damaged organelles and long-lived proteins. Autophagy is initiated by the formation of a cytoplasmic double membrane that grows to make a double membrane vesicle that engulfs intracellular components. This vesicle is subsequently transported to and fuses with a lysosome and the content is degraded by lysosomal hydrolases. Tissue specific, genetic ablation of core autophagy genes results in neurodegeneration or loss of cardiomyocyte function. Several autophagy genes have been identified as tumor suppressors. We have identified how this catabolic route may select damaged cellular components. The proteins p62 (SQSTM1) and NBR1 both contain a UBA domain that binds ubiquitinated proteins and a peptide motif (LIR) that directly binds to Atg8-family members (LC3/ GABARAP) located on the forming autophagosomal membranes. This way, p62 and NBR1 physically link damaged, ubiquitinated proteins to the forming autophagosomal membrane and lysosomal destruction.

With p62 in focus, we now search for conditions or components that speed up the autophagic flux. The aim is to increase the removal of damaged cellular components to prevent diseases to develop. On the other side, autophagy is often directly or indirectly down-regulated in cancer cells. How this dampening of autophagy could represent a drug target in particular cancer cells will be discussed.

Published: 24 September 2010

Correspondence: geir.bjorkoy@hist.no

University College of Sør-Trøndelag, Trondheim, Norway and University of Tromsø, Tromsø, Norway

\section{BioMed Central}

๑ 2010 Bjørkøy; licensee BioMed Central Ltd.

\section{doi:}

Cite this article as: Bjørkøy: Autophagy turns specific: the discovery of p62 and NBR1 as autophagy cargo receptors. BMC Proceedings 20104 (Suppl 2):016.
Submit your next manuscript to BioMed Central and take full advantage of:

- Convenient online submission

- Thorough peer review

- No space constraints or color figure charges

- Immediate publication on acceptance

- Inclusion in PubMed, CAS, Scopus and Google Scholar

- Research which is freely available for redistribution

Submit your manuscript at www.biomedcentral.com/submit
C Biomed Central 